\title{
Silencing of human T-cell leukemia virus type I gene transcription by epigenetic mechanisms
}

Yuko Taniguchi ${ }^{1}$, Kisato Nosaka1,2, Jun-ichirou Yasunaga1, Michiyuki Maeda ${ }^{3}$, Nancy Mueller ${ }^{4}$, Akihiko Okayama ${ }^{5}$ and Masao Matsuoka*1

Address: ${ }^{1}$ Laboratory of Virus Immunology, Institute for Virus Research, Kyoto University, Kyoto 606-8507, Japan, ${ }^{2}$ Department of Hematology, Kumamoto University School of Medicine, Kumamoto 860-8556, Japan, ${ }^{3}$ Laboratory of Infection and Prevention, Institute for Virus Research, Kyoto University, Kyoto 606-8507, Japan, ${ }^{4}$ Department of Epidemiology, Harvard School of Public Health, Boston, Massachusetts 02115, USA and ${ }^{5}$ Department of Laboratory Medicine, Faculty of Medicine, University of Miyazaki, Miyazaki 889-1692, Japan

Email: Yuko Taniguchi - yutanigu@virus.kyoto-u.ac.jp; Kisato Nosaka - knosaka@fc.kuh.kumamoto-u.ac.jp; Junichirou Yasunaga - jyasunag@virus.kyoto-u.ac.jp; Michiyuki Maeda - mimaeda@virus.kyoto-u.ac.jp; Nancy Mueller - nmueller@epinet.harvard.edu; Akihiko Okayama - okayama@med.miyazaki-u.ac.jp;

Masao Matsuoka*-mmatsuok@virus.kyoto-u.ac.jp

* Corresponding author

Published: 22 October 2005

Retrovirology 2005, 2:64 doi:10.1186/1742-4690-2-64

This article is available from: http://www.retrovirology.com/content/2/1/64

(c) 2005 Taniguchi et al; licensee BioMed Central Ltd.

This is an Open Access article distributed under the terms of the Creative Commons Attribution License (http://creativecommons.org/licenses/by/2.0), which permits unrestricted use, distribution, and reproduction in any medium, provided the original work is properly cited.
Received: 31 August 2005

Accepted: 22 October 2005

\begin{abstract}
Background: Human T-cell leukemia virus type I (HTLV-I) causes adult T-cell leukemia (ATL) after a long latent period. Among accessory genes encoded by HTLV-I, the tax gene is thought to play a central role in oncogenesis. However, Tax expression is disrupted by several mechanims including genetic changes of the tax gene, deletion/hypermethylation of 5'-LTR. To clarify the role of epigenetic changes, we analyzed DNA methylation and histone modification in the whole HTLV-I provirus genome.
\end{abstract}

Results: The gag, pol and env genes of HTLV-I provirus were more methylated than pX region, whereas methylation of 5'-LTR was variable and 3'-LTR was not methylated at all. In ATL cell lines, complete DNA methylation of 5'-LTR was associated with transcriptional silencing of viral genes. HTLV-I provirus was more methylated in primary ATL cells than in carrier state, indicating the association with disease progression. In seroconvertors, DNA methylation was already observed in internal sequences of provirus just after seroconversion. Taken together, it is speculated that DNA methylation first occurs in the gag, pol and env regions and then extends in the 5' and 3' directions in vivo, and when 5'-LTR becomes methylated, viral transcription is silenced. Analysis of histone modification in the HTLV-I provirus showed that the methylated provirus was associated with hypoacetylation. However, the tax gene transcript could not be detected in fresh ATL cells regardless of hyperacetylated histone $\mathrm{H} 3$ in 5'-LTR. The transcription rapidly recovered after in vitro culture in such ATL cells.

Conclusion: These results showed that epigenetic changes of provirus facilitated ATL cells to evade host immune system by suppressing viral gene transcription. In addition, this study shows the presence of another reversible mechanism that suppresses the tax gene transcription without DNA methylation and hypoacetylated histone. 


\section{Background}

Human T-cell leukemia virus type I (HTLV-I) is associated with a neoplastic disease, adult T-cell leukemia (ATL), and inflammatory diseases, such as HTLV-I-associated myelopathy (HAM)/tropical spastic paraparesis (TSP) and HTLV-I-associated uveitis $[1,2]$. Among HTLV-I carriers, a part of infected individuals develop ATL after a long latent period. During the leukemogenesis by HTLV-I, Tax protein is considered to play a critical role through its pleiotropic actions, which include transactivation of NF- $\kappa \mathrm{B}$, CREB and SRF pathways, transrepression of $l c k, p 18$ and DNA polymerase $\beta$ gene transcriptions, and functional inactivation of p53 and MAD1 [3-6]. Through these actions, Tax induces the proliferation of HTLV-I infected cells and inhibits their apoptosis, resulting in an increase in the number of infected cells. However, since Tax protein is the major target of cytotoxic T-lymphocytes (CTLs) in vivo, the expression also has a negative effect on the survival of ATL cells [7-9]. In some ATL cells, tax gene expression is inactivated by genetic and epigenetic changes, which include deletion, insertion or mutation of the tax gene, and DNA methylation or deletion of 5'-LTR [10-13]. Such inactivation of Tax expression is considered to allow ATL cells to escape from the host immune system.

DNA methylation of retroviruses is regarded as a host defense mechanism for inactivating retrovirus expression [14]. However, it is also recognized as a mechanism for virus-infected cells to escape from the host immune system and establish the latent state. In contrast, human immunodeficiency virus (HIV) is resistant to silencing in vivo. It is because HIV is frequently integrated into active transcriptional unit in vivo [15]. These findings coincide with the fact that HIV vigorously replicates in vivo. On the other hand, DNA methylation accumulated in HTLV-I 5'LTR has been shown to silence viral gene transcription in leukemic cells $[12,13]$. In addition, the frequency of integration of HTLV-I provirus into transcriptional units was equivalent to that calculated based on random integration [16], which also increased the silencing. It remains unclear where and when DNA methylation occurs within the HTLV-I provirus genome.

In this study, we analyzed DNA methylation and histone modification in the whole HTLV-I provirus, and observed the progressive accumulation of DNA methylation. In addition, another reversible mechanism silenced viral gene transcription regardless of hyperacetylated promoter region.

\section{Results \\ Analyses of DNA methylation of HTLV-I provirus}

To reveal DNA methylation status within the HTLV-I provirus, we analyzed the DNA methylation by sodium bisulfite sequencing and combined bisulfite restriction analysis (COBRA). Initially, DNA methylation in 5'-LTR, gag, pol, env, pX and 3'-LTR was identified by sodium bisulfite sequencing. In an ATL case (Fig. 1A), the internal regions of the HTLV-I provirus, including gag, pol and env, were heavily methylated. On the other hand, 5'-LTR and $\mathrm{pX}$ were partially methylated, and 3'-LTR was not methylated at all. In an ATL cell line, ATL-48T (Fig. 1A), the internal sequences of the HTLV-I provirus were partially methylated, whereas both LTRs were not methylated. Since the analyses by sodium bisulfite sequencing were time-consuming, we established the COBRA method to detect and analyze DNA methylation in a large number of samples, and then compared the results obtained with the two methods. After amplification of sodium bisulfite treated DNAs with each primer sets, the products were digested with TaqI or AccII, which contain one (TaqI) or two (AccII) CpG site(s) within the recognition sequences. When $\mathrm{CpG}$ site is methylated, the products retain $\mathrm{CpG}$ site, resulting in digestion by these enzymes. On the other hand, CpG is converted to UG when it is unmethylated. Therefore, PCR products are resistant to restriction enzymes (Fig. 1B). With the COBRA method, the extent of DNA methylation was quantified in eight CpG sites throughout the HTLV-I provirus: 5'-LTR (620 according to the numbering by Seiki et al. [17]), gag (1753), pol (2988, 4187 and 5151), env (6113), pX (7258) and 3'-LTR (8342) (Fig. 1C). The extent of DNA methylation detected by the COBRA method was well correlated with that obtained by sodium bisulfite sequencing in both cases studied, as shown in Fig. 1A and 1C.

\section{DNA methylation throughout the HTLV-I provirus in HTLV-l-transformed and ATL cell lines}

Using the COBRA method, we analyzed the DNA methylation throughout the whole HTLV-I provirus of the cell lines (Fig. 2B and 2C). In addition, we also analyzed the tax gene transcription by RT-PCR (Fig. 2A) and the number of integrated HTLV-I proviruses in each cell lines by Southern blot method. Among the tax gene-expressing cell lines (ATL-35T, MT-2, Sez627, MT-4, ATL-55T, MT-1 ATL-48T and ATL-2) (Fig. 2A), internal sequences from gag to pX were variably methylated. However, 5'-LTR was not methylated or partially methylated, while 3'-LTR was not methylated in all cell lines (Fig. 2B). In ATL-43T and TL-Oml, which did not show tax gene transcription (Fig. 2A), 5'-LTR and the internal sequences were heavily methylated (Fig. 2C), indicating the close correlation between the extents of DNA methylation of the provirus, particularly 5'-LTR, and tax gene transcription. As previously reported, the treatment by 5-aza-deoxy-cytidine can recover the tax gene expression of these cell lines, indicating that the latent state by DNA methylation of 5'-LTR is reversible [13]. 
A

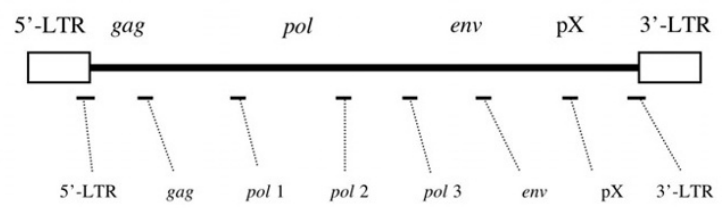

Acute ATL
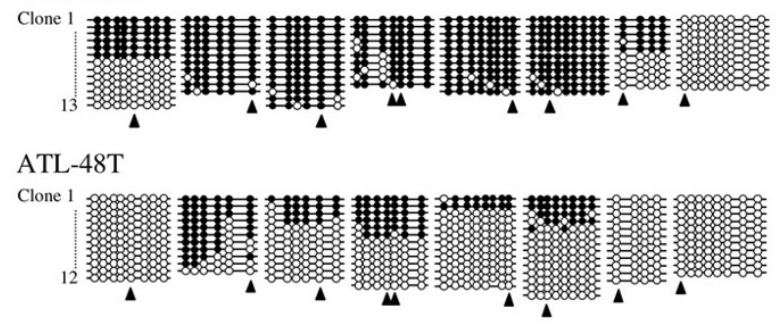

B

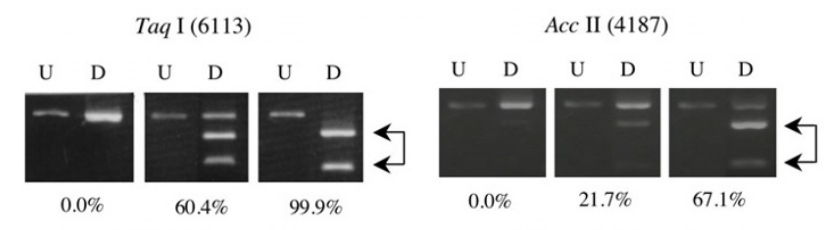

C
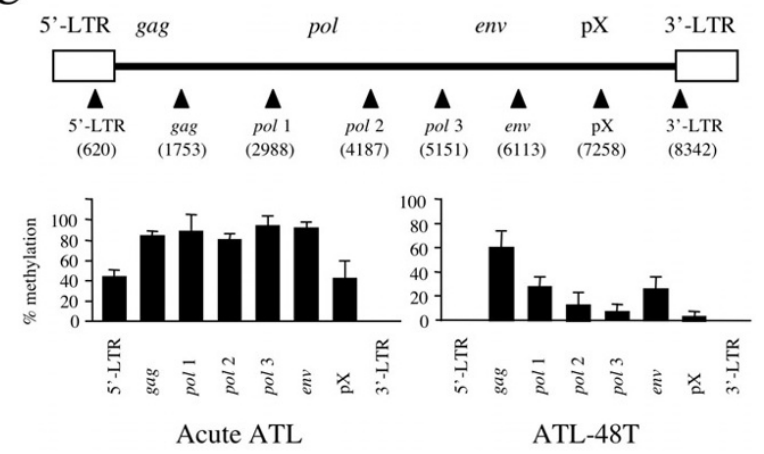

Figure I

DNA methylation of the HTLV-I provirus assessed by sodium bisulfite sequencing and COBRA. A. DNA methylation in the HTLV-I provirus was analyzed by sodium bisulfite sequencing in a case of acute ATL and a tax gene-expressing cell line, ATL-48T. Eight DNA regions, which were represented as bars in A, were amplified with sodium bisulfite treated DNA. The PCR products were subcloned into plasmid DNA, and then the sequences of each clone were determined for at least ten clones of each region. Arrowheads indicate the $C_{P} G$ sites that were target sites for COBRA. Closed circle indicates methylated $C_{P G}$, and open circle means unmethylated $C_{P G}$. The number of integrated provirus has been shown in parenthesis. $B$. Representative data of COBRA has been shown. PCR products, which were amplified with sodium bisulfite treated DNAs, were digested with Taql or Accll. The extent of methylation in each CPG site was measured as described in Methods, and presented as percentages of methylated CPG. The number in parenthesis represents the position of cytidine residue in analyzed CPG site by COBRA according to Seiki et al. [4I]. C. DNA methylation studied by COBRA at eight points in the provirus as shown by arrowheads. Each bar represented the extent of DNA methylation at the points shown by arrowhead. The analyses by COBRA were performed three times independently, and the extents of DNA methylation are shown by the mean \pm SD. The number in parenthesis shows the position of cytidine residue of $C_{p} G$ site analyzed by COBRA. 
A Cell lines

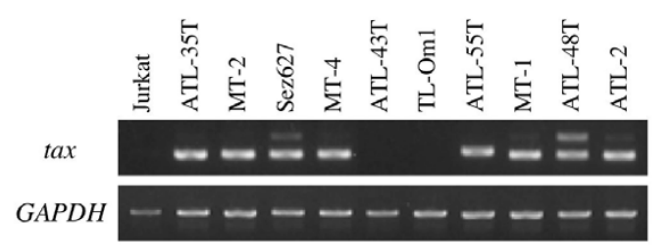

B
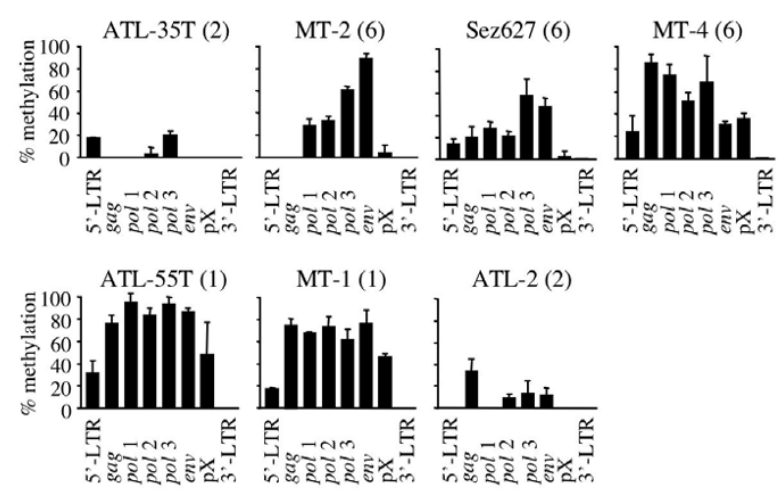

C

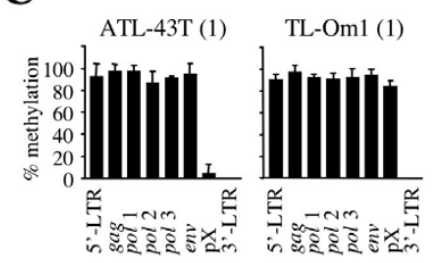

D

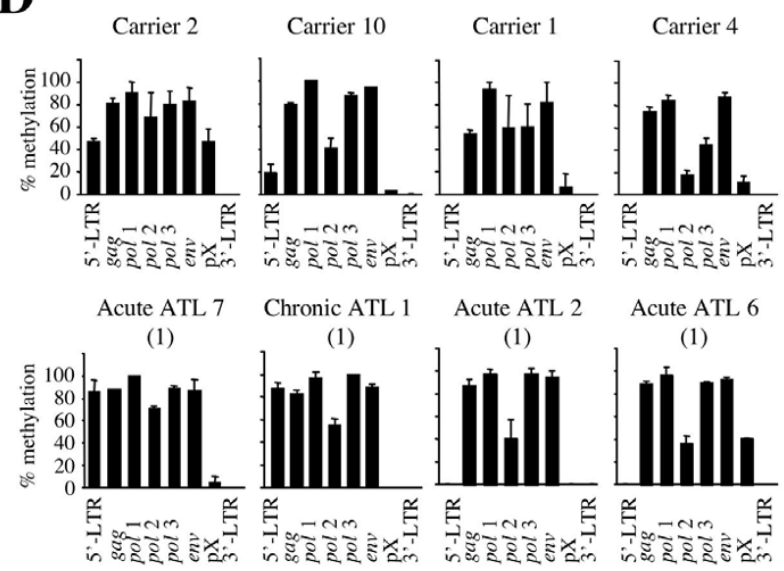

Figure 2

DNA methylation in ATL cell lines, HTLV-I carriers and ATL cases. The tax gene transcription in ATL cell lines was studied by RT-PCR (A), and the expression of GAPDH gene has been used as a control. DNA methylation throughout the HTLV-I provirus was studied by COBRA in tax gene-expressing (B) and non-expressing cell lines (C). Furthermore, DNA methylation was also analyzed in 20 carriers and 20 ATL cases by COBRA, and representative patterns of DNA methylation are shown in D. The number of HTLV-I provirus has been analyzed by Southern blot method, and shown in the parenthesis (B, $C$ and D). Each bar indicates the extent of DNA methylation that was calculated by COBRA. 
A
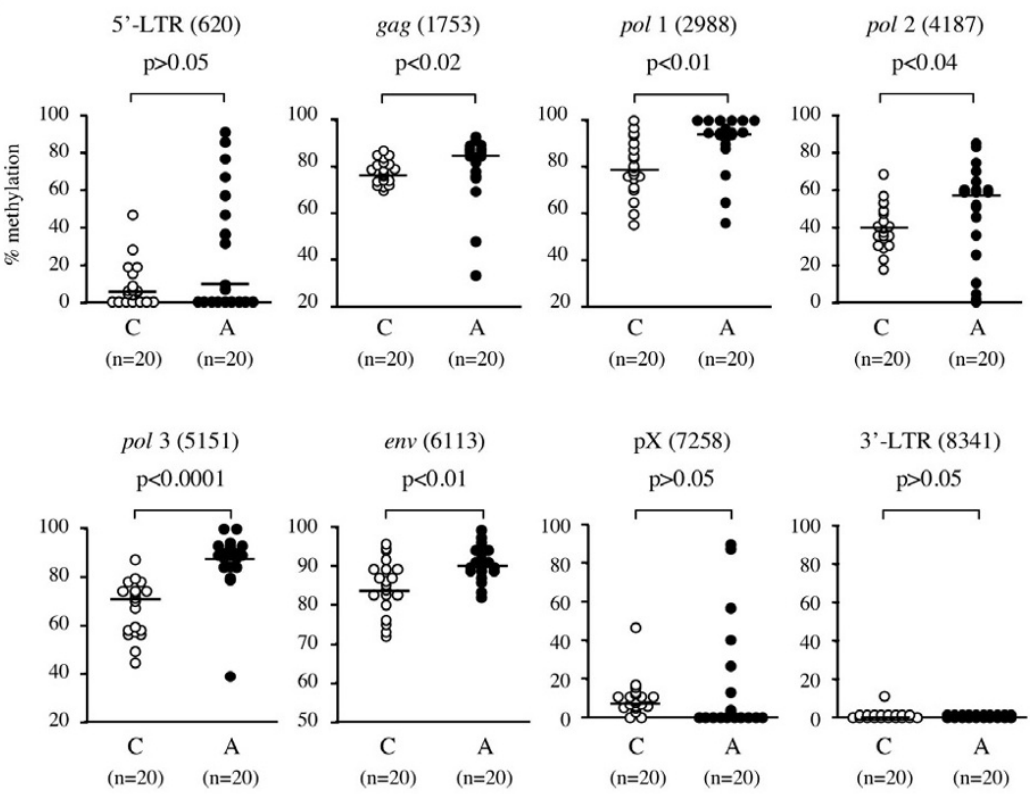

B

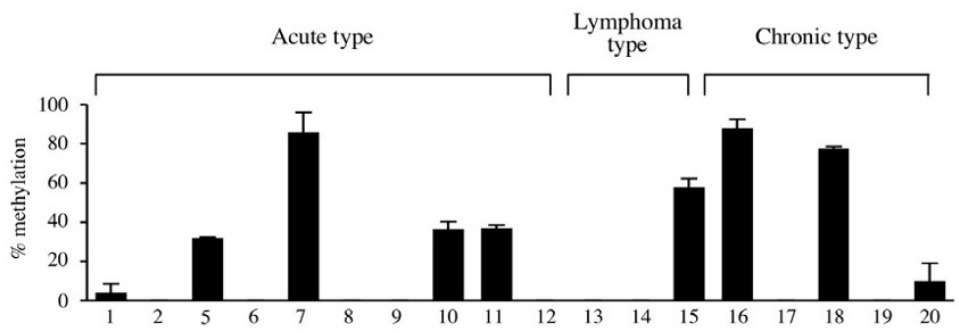

$\operatorname{tax}$

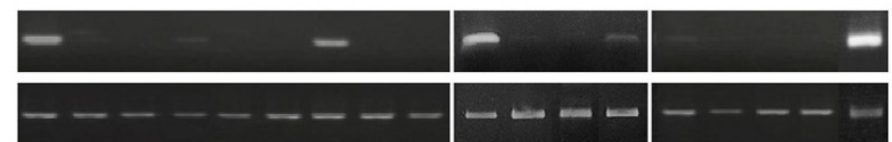

GAPDH

Figure 3

Comparison of the DNA methylation in carriers and ATL cases. A. DNA methylation at eight different regions in the HTLV-I provirus was compared between carriers (C) and ATL cases (A). DNA methylation was quantified by COBRA in 20 carriers and 20 ATL cases. Each sample was analyzed three times by COBRA at each site, and circles indicate mean values of DNA methylation. The differences of DNA methylation are statistically significant in the gag, pol and env regions by the MannWhitney's U-test. Horizontal bars represent median of DNA methylation in each group. B. The relation between tax gene transcription and DNA methylation of 5'-LTR in the fresh ATL cells has been shown. DNA methylation of 5'-LTR was quantified by COBRA assay and the tax gene transcripts were detected by RT-PCR. 
A

A Seroconverter 1
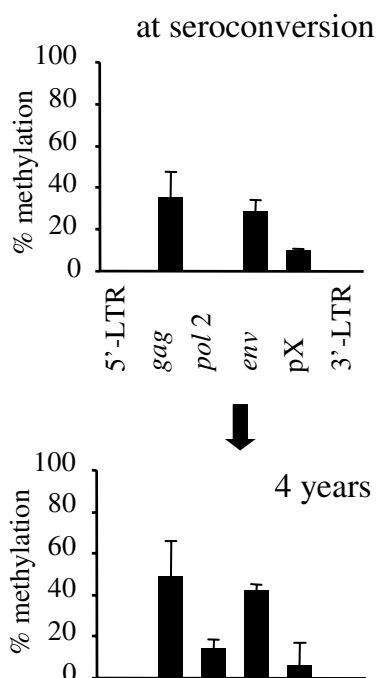

0

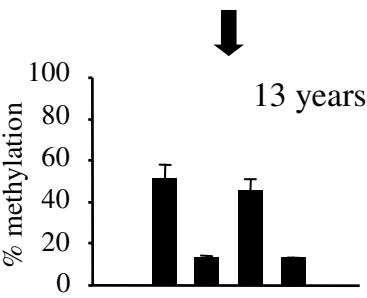

B

ATL-21C

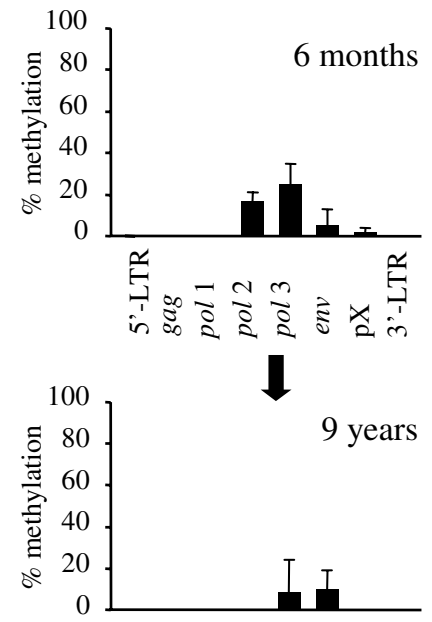

Seroconverter 2
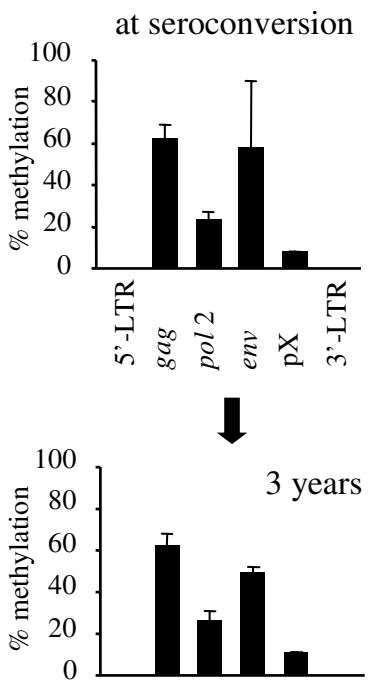

.


A

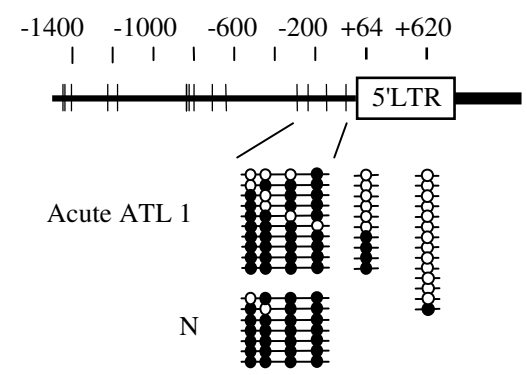

C

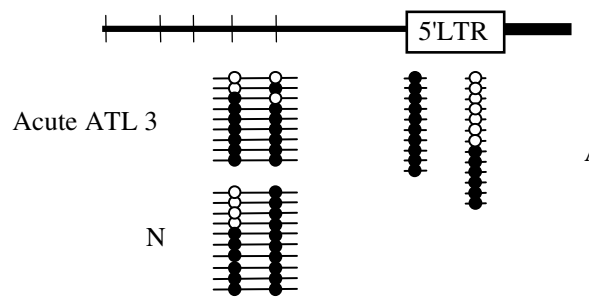

$\mathbf{E}$

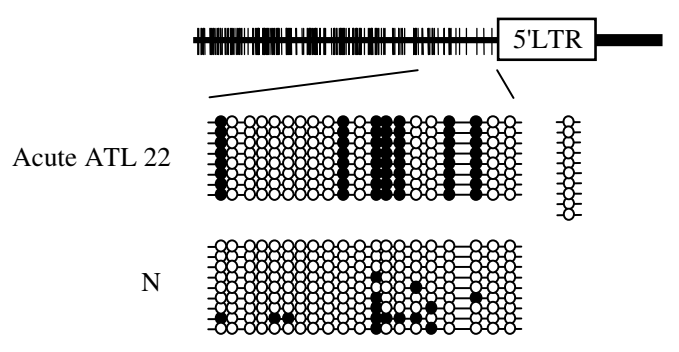

B

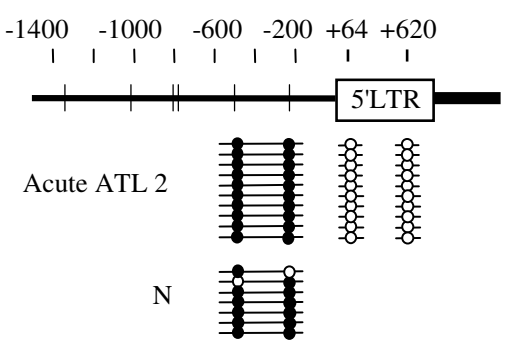

D

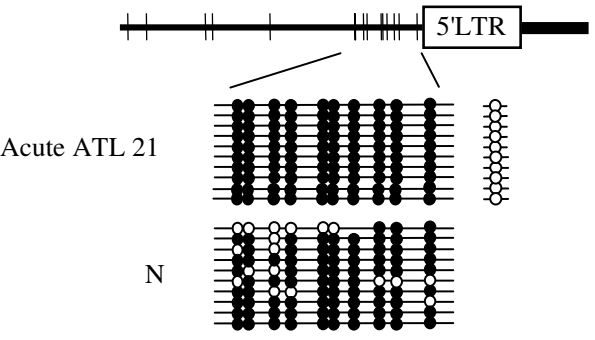

$\mathbf{F}$

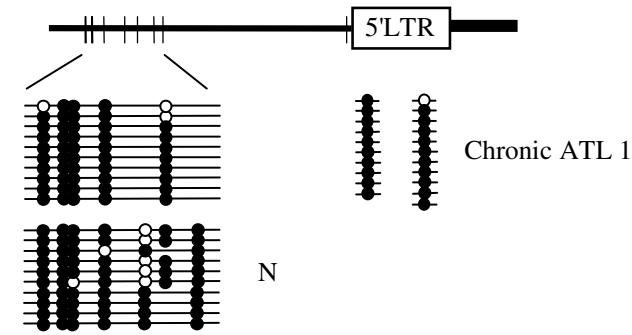

Figure 5

DNA methylation of provirus is not associated with methylated CpG sites in the genome. Integration sites of HTLV-I provirus in leukemic cells have been determined by inverse PCR, and then DNA methylation in genome has been analyzed by sodium bisulfite sequencing. DNA methylation of $5^{\prime}$-LTR was also analyzed by sodium bisulfite sequencing method. Vertical bars represent $C_{p} G$ sites. Open circle indicates unmethylated $C_{p} G$ site, and closed one means methylated $C_{p} G$ site. $\mathrm{N}$ : normal PBMCs from non-carrier donor. 
Among cell lines, HTLV-I provirus tends to be not so methylated in cell lines with higher copy number of provirus (Fig. 2). The finding that cell lines with higher integrated provirus number contain hypomethylated provirus is speculated to reflect the higher transcription of viral genes.

\section{DNA methylation of the HTLV-I provirus in ATL and HTLV- I carrier states}

Next, we analyzed the DNA methylation of the whole HTLV-I provirus in ATL patients and HTLV-I carriers. Although 5'-LTR is frequently deleted in ATL cells [10], we omitted such ATL cases lacking 5'-LTR in this study. In Fig. $2 \mathrm{D}$, we showed the representative pattern of DNA methylation of whole HTLV-I provirus in carriers and ATL patients. In ATL samples, the gag, pol and env regions were heavily methylated, whereas 5'-LTR was not methylated or partially methylated (Fig. 2D and 3A). On the other hand, 5'-LTR was scarcely methylated and the gag, pol and env regions seemed to be less methylated in HTLV-I carriers (Fig. 2D and 3A). We compared DNA methylation of these different eight regions between 20 carriers and 20 ATL cases (Fig. 3A). These differences in DNA methylation were statistically significant in the gag, pol and env regions between the ATL cases and HTLV-I carriers by the Mann-Whitney's U-test. These data suggested that DNA methylation initially occurred in the gag, pol, and env regions, and that DNA methylation of the provirus accumulated during disease progression from the carrier state to the leukemic stage. The frequency of DNA methylation of 5'-LTR did not differ between carriers and ATL patients. However, the extent of DNA methylation among methylation-positive cases was higher in ATL cases than in carriers $(\mathrm{p}=0.001)$. Among ATL cases, the relationship between DNA methylation of 5'-LTR and tax gene transcription was analyzed (Fig. 3B), and the transcript was detected in six cases. In four cases with relative higher amount of tax gene transcripts (Case 1, 9, 12, 20), 5 '-LTR was not methylated or slightly methylated. This finding suggests that higher expression of tax gene is associated with unmethyalted or slightly methylated 5'LTR, however, other mechanism(s) silences the tax gene transcription in ATL cells. There is no statistical correlation between the tax gene transcription and DNA methylation of 5'-LTR

DNA methylation of HTLV-I provirus after seroconversion The analyses of DNA methylation suggest that it first occurs around the gag, pol and env regions, and then progresses in both the 5 ' and 3 ' regions. To study the changes in DNA methylation after infection, we analyzed sequential DNA samples from seroconverters. As shown in Fig. 4A, DNA methylation already existed in the gag, pol and env regions at the seroconversion. In seroconverter 1, DNA methylation was slightly increased at 4 and
13 years after the seroconversion. Increase of DNA methylation at pol region (4187) is statistically significant 13 years later in seroconverter 1 ( $p=0.02$, by a Student's ttest). On the other hand, there was little change in the DNA methylation in seroconverter 2, although the HTLVI provirus was already heavily methylated at the seroconversion. When DNA methylation of seroconverters was compared with that in carriers (Fig. 3A), provirus of carriers was more methylated in carriers than that of seroconverters ( $\mathrm{p}<0.01$ by a Student's t-test) except for pol 2 in seroconverter 2, and pX region. It suggests that DNA methylation of provirus accumulates during a latent period after seroconversion.

We established an HTLV-I-transformed cell line, ATL-21C, and cultured for over 9 years in vitro, and analyzed the DNA methylation of the HTLV-I provirus. Slight DNA methylation was detected in the pol, env and $\mathrm{pX}$ regions at 6 months after culture, however, it did not increase after 9 years. This indicates that the DNA methylation of HTLV-I provirus did not change after long-term in vitro culture (Fig. 4B). On the other hand, the $p 16$ gene in this cell line was not methylated at 6 months after culture, but heavily methylated after 9 years (data not shown). A comparison with the data from the seroconverters suggests that DNA methylation of the HTLV-I provirus tends to accumulate in vivo.

\section{Association with DNA methylation in the neighboring host genome}

It is possible that the HTLV-I provirus integrated into the heterochromatin or hypermethylated regions tends to be silenced [18], and that such HTLV-I-infected cells are selected in vivo. Therefore, we analyzed the DNA methylation of the host genome around the integration sites of the HTLV-I provirus. We first determined the integration sites of the HTLV-I provirus in ATL cells, and then analyzed the DNA methylation of genomic DNAs around the integration sites in both ATL cells and normal PBMCs from a non-carrier donor. When genomic DNAs neighboring integration sites were heavily methylated (Fig. 5), 5'-LTR was not methylated in three cases (acute ATL 1, 2 and 21) while they were methylated in two cases (acute ATL 3 and chronic ATL 1). In acute ATL 22, both genomic DNA and 5'-LTR were not so methylated. Thus, DNA methylation in the neighboring genomic regions was not correlated with the methylation status of the provirus among these cases.

\section{Histone modification of the HTLV-I provirus}

It has been demonstrated that DNA methylation of 5'-LTR is associated with histone deacetylation and silencing of viral gene transcription in cell lines [13]. When ATL-43T, in which tax gene transcription was silenced by hypermethylation of 5'-LTR, was compared with a tax gene- 
A

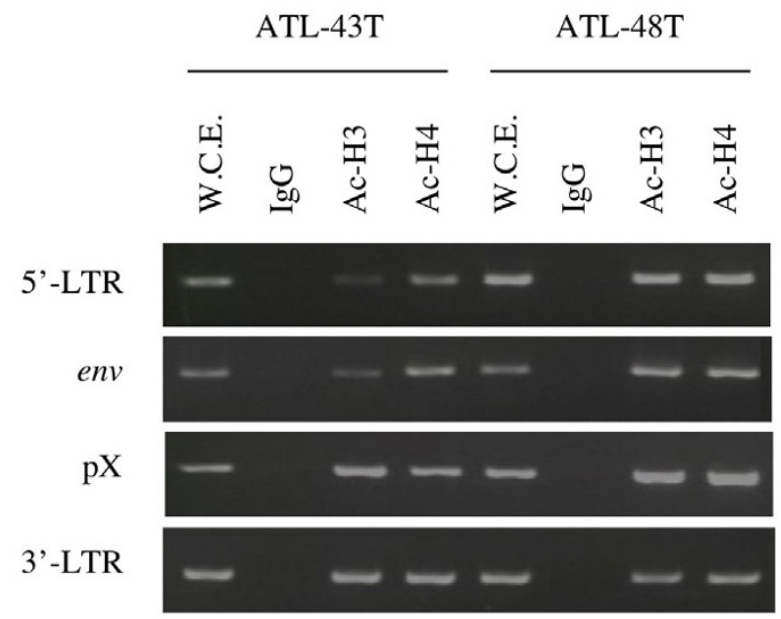

B

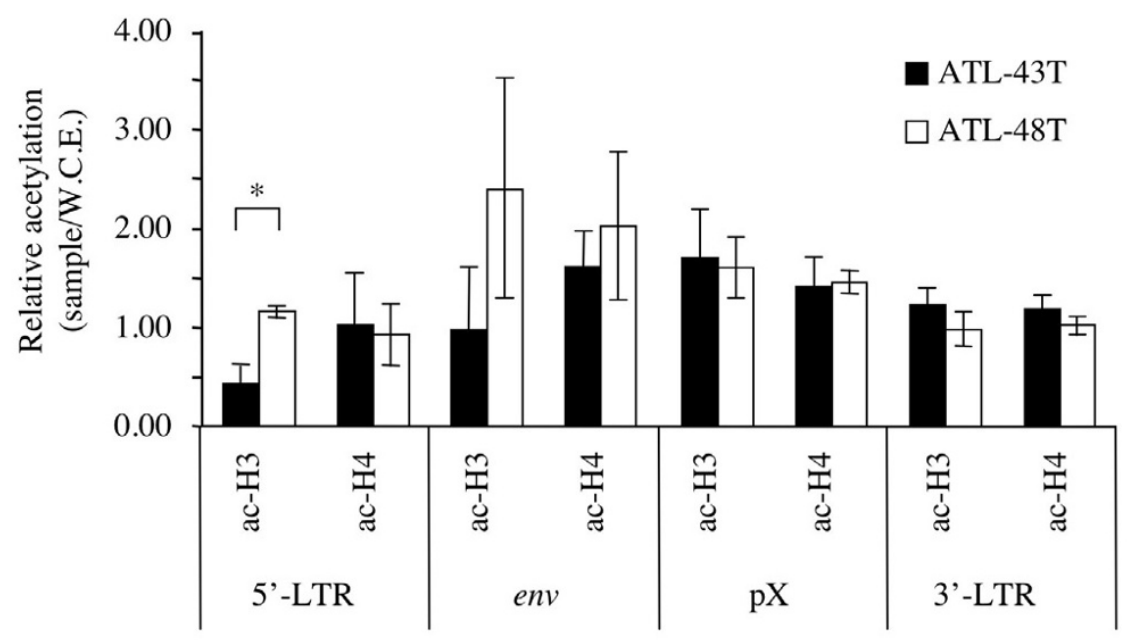

Figure 6

Histone modifications in ATL cell lines. Acetylation of histone was analyzed in tax gene-expressing (ATL-48T) and nonexpressing (ATL-43T) cell lines by ChIP assays with anti-acetyl-Histone H3 or H4 (A and B) at four different regions (for 5'LTR, env, pX and 3'-LTR) of the provirus. Representative data has been shown in A. W.C.E.: whole cell extract. ChIP assay was performed three times and quantified as described in Methods. Values are means $\pm \operatorname{SD}(B)$. *:p $<0.002$. 
A

Case $1 \quad$ Case $2 \quad$ Case 3

$\begin{array}{lll}\text { HTLV-I provirus } & \begin{array}{l}1 \text { copy } \\ \text { Complete type }\end{array} & 1 \text { copy } \\ \text { Type } 1 \text { defective type } & \text { Complete type }\end{array}$

$\operatorname{tax}$ RT-PCR

$(+)$

$(-)$

$(-)$

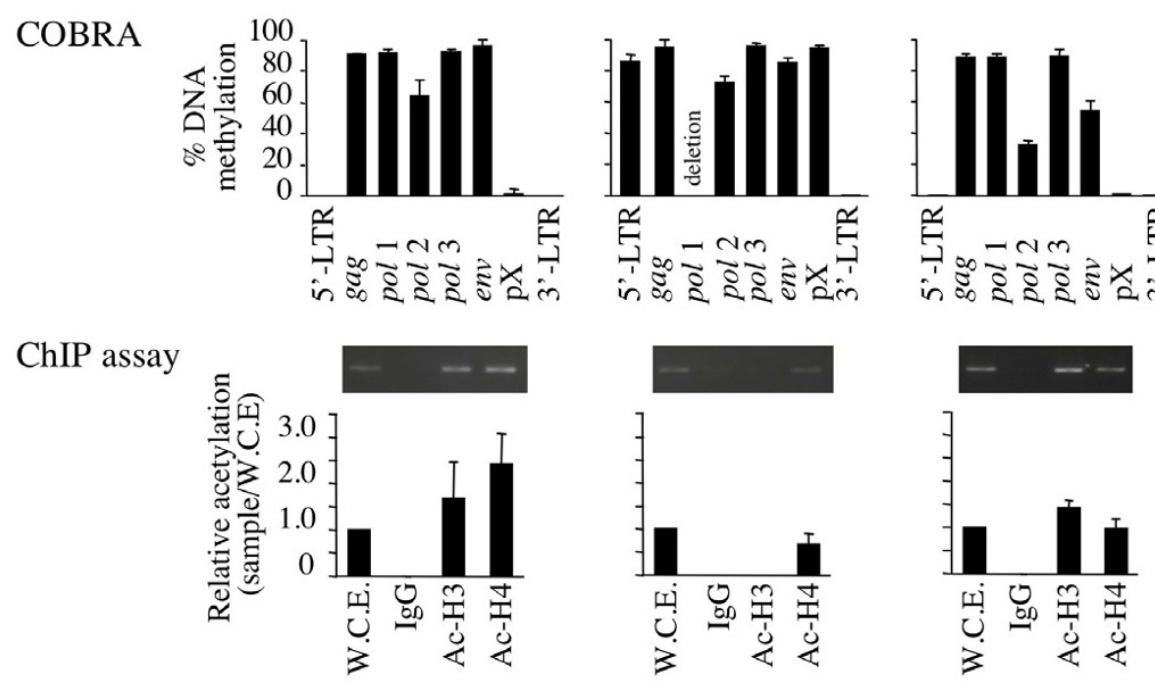

B

\begin{tabular}{|c|c|c|c|c|}
\hline \multirow[b]{2}{*}{$\mathrm{hr}$} & \multicolumn{4}{|c|}{ Case 3} \\
\hline & 0 & 1 & 3 & 6 \\
\hline $\operatorname{tax}$ & & & - & 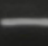 \\
\hline GAPDH & 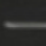 & - & - & - \\
\hline
\end{tabular}

Figure 7

DNA methylation and histone modifications in fresh ATL cases. A. The relationships among DNA methylation, tax gene expression and histone modification in 5'-LTR were analyzed in three ATL cases. Cases I and 3 have one copy of the complete HTLV-I provirus, while Case 2 has a defective provirus that lacks part of the pol gene. DNA methylation was analyzed by COBRA. The tax gene transcripts could be detected in Case I, but not in Cases 2 or 3, by RT-PCR. ChIP assays were also performed using primers for 5'-LTR to analyze acetylation of histone $\mathrm{H} 3(\mathrm{Ac}-\mathrm{H} 3)$ and $\mathrm{H} 4$ (Ac-H4). W.C.E.: whole cell extract. B. Recovery of tax gene expression ex vivo. The PBMCs isolated from Case 3 were immediately cultured ex vivo for several hours and tested the transcription of tax mRNA by RT-PCR. 
expressing cell line, ATL-48T, a difference was found in the acetylation of histone $\mathrm{H} 3$ in 5 '-LTR (Fig. 6A and 6B). The histone H3 of 5'-LTR was hypoacetylated in ATL-43T compared with ATL-48T, whereas there were no differences in pX or 3'-LTR among these cell lines. Since the number of HTLV-I provirus in ATL-43T and -48T is one and two copies respectively, and acetylation of histone $\mathrm{H} 3$ in $\mathrm{pX}$ and 3'-LTR was similar in both cell lines, the number of provirus was thought to have no influence on the results of ChIP assay in 5'-LTR.

However, the tax gene transcription is silenced in about $20 \%$ of ATL cases despite no or partial methylation of 5'LTR (Fig. 3B) [13], suggesting that there is aother mechanism(s) for suppressing viral gene transcription. To address this question, we studied the histone modification of 5'-LTR in fresh ATL cells with or without tax gene transcription. In a case with tax gene expression, 5'-LTR was not methylated and histone $\mathrm{H} 3$ was hyperacetylated (Fig. 7A, Case 1). On the other hand, in Case 2 with heavily methylated 5'-LTR, histone H3 was hypoacetylated in 5 '-LTR, which was consistent with the lack of detection of tax gene transcription in this case. However, in Case 3, tax gene transcription could not be detected regardless of 5'LTR hyperacetylation. After in vitro culture, such cells showed tax gene transcription within one hour (Fig. 7B). Although both Cases 1 and 3 exhibited hyperacetylation of 5'-LTR, tax gene transcription was silenced in Case 3.

\section{Discussion}

DNA methylation is regarded as a host defense mechanism for inactivating transportable elements such as retroviruses to inhibit viral transcription and the generation of new viruses. On the other hand, it also renders the provirus into a latent state, resulting in the establishment of latent infection. However, it remained unclear how and when the provirus was methylated, and whether DNA methylation changed in vivo.

Tax has the remarkable potency to promote the proliferation of infected cells [3], however, it is also a major target of CTL in vivo [8]. Therefore, HTLV-I controls tax gene expression by own viral proteins, Rex [19], p30 [20,21] and HBZ [22]. In the leukemic cells, several mechanisms have been identified to suppress or abolish Tax expression, including genetic changes of tax gene, deletion of 5'LTR, and DNA methylation of 5'-LTR. In this study, DNA methylation was shown to occur in internal provirus sequences, such as the gag, pol and env regions, and then extend to 5' (5'-LTR) and $3^{\prime}(\mathrm{pX})$ regions. Since DNA methylation of $5^{\prime}$-LTR is associated with tax gene transcription, the finding that 5'-LTR was more highly methylated in ATL cells than in carriers, among cases with methylated 5'-LTR, suggests that such HTLV-I-infected cells and ATL cells with the methylated provirus, which produce lower amounts of viral proteins, are selected in vivo by the host immune system. In this regard, HTLV-I is quite different from another human retrovirus, HIV-1. HIV-1 vectors were resistant to gene silencing in vivo $[23,24]$. It is noteworthy that the number of CpG sites in the U3 region of HIV-1 LTR ( 9 sites in LTR of NL43) is much fewer than that of HTLV-I (47 sites in LTR of ATK). This is consistent to the previous report that transcriptional suppression was not associated with DNA methylation of HIV-1 provirus [25]. In addition, HIV-1 provirus is frequently integrated within transcriptional units, which encode the genes that are transcribed in T-cells $[15,26]$. In such regions, it is possible that HIV-1 tends to escape from transcriptional silencing that is observed in the heterochromatin region such as alphoid repetitive sequences [18]. These data suggest that HIV-1 is more resistant to gene silencing than HTLV-I. Alternatively, it is possible that HTLV-I takes advantage of susceptibility to DNA methylation to escape from the host immune system.

This study shows that 3 '-LTR is unmethylated in carriers and ATL cells while 5'-LTR is methylated in about half of cases. In HTLV-I, HTLV-I bZIP (HBZ) gene is encoded by minus strand of provirus $[22,27]$. We observed that $H B Z$ gene was transcribed in all ATL cells, suggesting that $H B Z$ gene play a critical role in growth of HTLV-I infected cells and ATL cells (submitted for publication). The finding that 3'-LTR is unmethylated in all ATL cases and carriers suggests that $H B Z$ gene transcription is important for proliferation of ATL and HTLV-I infected cells.

Why does DNA methylation occur from the internal sequences of the HTLV-I provirus? Since CpG island is recognized as DNA region that is susceptible to DNA methylation, we analyzed HTLV-I provirus by the criterion by Takai and Jones [28]. CpG islands are present throughout the provirus in 5'-LTR-gag (1-1360), pol (3876-4509), env (5648-6166), env-pX (6446-7561), and pX-3'-LTR (8212-9045) regions. Therefore, the presence of CpG island could not explain why DNA methylation occurred in the internal region of HTLV-I provirus. Among tumorsuppressor genes, which are transcriptionally silenced by DNA methylation, the exon regions are first methylated, and then DNA methylation progresses to the promoter region [29]. When the promoter region is heavily methylated, the transcription of the corresponding gene is silenced. Since 5'-LTR is the promoter/enhancer for viral gene transcription, there might be a similar scenario between the exon/promoter and DNA methylation in both virus and tumor-suppressor genes. Thus, it is possible that gene coding regions are first methylated and DNA methylation spreads to the promoter region of provirus, 5'-LTR. 
Transcriptional silencing of tax gene in spite of hyperacetylated histone $\mathrm{H} 3$ is recognized as another mechanism to suppress the viral gene transcription in addition to DNA methylation. The prompt recovery of tax gene expression after in vitro culture suggests the presence of an inhibitory factor(s) that binds to 5'-LTR, and suppresses the viral gene transcription in vivo. It is noteworthy that this phenotype is very similar to that of a mouse T-cell line transfected with an HTLV-I LTR-derived reporter plasmid [30]. In that study, a green fluorescent protein-fused Tax (Gax) gene was transfected into a mouse T-cell line, EL-4, and the transduced cells were then injected into Taximmunized and non-immunized mice. Although Taxinduced cytotoxic T-cells suppressed the expression of the Gax gene in vivo, its expression was shown to recover within three hours when the transduced cells were transferred to in vitro culture. This phenotype resembles that observed in Case 3 in Fig. 7. Considering that Tax is the major target of CTL in vivo, and at the same time, confers growth advantages on the infected cells, such reversible suppression of tax gene expression is thought to be suitable for the survival of HTLV-I infected cells, and ATL cells. In this regard, potentiation of anti-Tax immunity might protect against the development of ATL when combined with possible therapeutics to induce Tax expression [31]. For this purpose, the mechanism for silencing viral transcription regardless of histone $\mathrm{H} 3$ hyperacetylation should be studied.

In general, gene silencing is associated with several different mechanisms. DNA methylation in the promoter region silences the gene transcription, whereas gene silencing is often not associated with DNA methylation $[32,33]$. In such situations, methylation of H3K9 is linked with loss of transcriptions [34]. It is possible that silencing of viral gene transcription renders proviral DNA vulnerable to methylation. Once proviral DNA is methylated, such silencing would be fixed unless such cells are treated with demethylating agents such as 5-aza-deoxy-cytidine.

DNA methylation of the HTLV-I provirus did not accumulate in a cell line that was cultured in vitro for more than 9 years. The finding that the $p 16$ gene was heavily methylated in this cell line excluded the possibility that hypermethylation did not occur in this cell line due to aberrant methylation machinery. Among the seroconverters, the provirus was heavily methylated in internal regions such as $g a g$, pol and env. Taken together, DNA methylation in the provirus is considered to reflect the selection in vivo. Since the growth of in vitro HTLV-I-transformed cell lines depends on Tax expression, cells with suppressed expression of the tax gene do not have the growth advantage in vitro. However, the immune system exerts selection of the infected cells with suppressed tax gene expression in vivo.
Recently, both 5'- and 3'-LTR have been reported to be transcriptionally active, and transcriptional factors and Tax bind equally to both [35]. 3'-LTR may activate the transcription of cellular genes, which are located in the downstream of integration sites. In addition, unmethylated 3'-LTR is critical for transcription of the HBZ gene. Since 5'-LTR is a promoter/enhancer for viral gene transcription, selective methylation of 5'-LTR is considered to silence the transcription of viral genes.

\section{Conclusion}

We have demonstrated how DNA methylation of HTLV-I provirus occurred, and how it suppressed viral gene transcription. When 5'-LTR was heavily methylated, viral transcription was silenced, which is thought to reflect the immune system selection in vivo. In addition, mechanisms other than DNA methylation suppresses viral gene transcription regardless of histone $\mathrm{H} 3$ hyperacetylation. The mechanism of such suppression requires further investigation.

\section{Methods \\ Cells}

HTLV-I-associated cell lines (MT-1, MT-2, MT-4, ATL-2, TL-Oml and Sez627) were cultured in RPMI1640 medium supplemented with $10 \%$ fetal bovine serum and penicillin/streptomycin. For interleukin-2-dependent cell lines (ATL-43T, 48T and 55T), $100 \mathrm{U} / \mathrm{ml}$ of recombinant interleukin-2 (Shionogi, Osaka) was added to the medium. Peripheral blood mononuclear cells (PBMC) or lymph node cells were isolated from HTLV-I carriers and ATL patients after informed consent was obtained. The polyclonal integration of HTLV-I provirus in carriers has been shown by inverse PCR [36], and provirus load was determined by real-time PCR as reported previously [37].

\section{Sodium bisulfite treatment of genomic DNA}

Sodium bisulfite treatment was performed as described previously [29]. Briefly, 1-3 $\mathrm{gg}$ of genomic DNA was denatured in $0.3 \mathrm{~N} \mathrm{NaOH}$ at $37^{\circ} \mathrm{C}$ for $15 \mathrm{~min}$, and $1 \mu \mathrm{g}$ of salmon sperm DNA was added to each sample as a carrier. Sodium bisulfite ( $\mathrm{pH}$ 5.0) and hydroquinone were added to each sample to final concentrations of $3 \mathrm{M}$ and $0.05 \mathrm{mM}$, respectively. The reaction was performed at $55^{\circ} \mathrm{C}$ for $16 \mathrm{~h}$ and the samples were then desalted using the Wizard DNA Clean-Up System (Promega, Madison, WI). Finally, samples were desulfonated in $0.3 \mathrm{~N} \mathrm{NaOH}$ at $37^{\circ} \mathrm{C}$ for $15 \mathrm{~min}$.

\section{Sequencing of sodium bisulfite-treated genomic DNA}

The sodium bisulfite-treated DNA (200-500 ng) was used as a template for PCR amplification of eight HTLV-I provirus regions. The PCR reactions were performed using FastStart Taq DNA Polymerase (Roche, Mannheim, Germany). The PCR primer pairs and annealing temperatures 
Table I: Primer sets for COBRA and ChIP assay

\begin{tabular}{|c|c|c|c|c|c|c|}
\hline & Site in HTLV-Ia & & Forward primer & Reverse primer & Anneal $\left({ }^{\circ} \mathrm{C}\right)$ & Enzyme for COBRA \\
\hline \multirow[t]{20}{*}{ COBRA } & 620 & Ist & 5'-TTTGGAGTTTATTTAGATTTAG-3' & 5'-CCAATAATAAACRACCAACCC-3' & 45 & Taql \\
\hline & $\left(5^{\prime}-L T R\right)$ & 2nd & 5'-GTTTTGTTTGATTTTGTTTGT-3' & 5'-AAAAAAATTTAACCCATTACC-3' & 49 & \\
\hline & 1753 & Ist & 5'-GGGAGTGTTAAAGATTTTTTTTGGGG-3' & 5'-ACTCCAATAACCTACTTTCCC-3' & 55 & Taql \\
\hline & (gag) & 2nd & 5'-TTTATTTTTTAAGGTTTGGAGGAG-3' & 5'-TTAAAAATCCAAATCTAACAAACCC-3' & 55 & \\
\hline & 2988 & Ist & 5'-GTTAAAAAGGTTAATGGAATTTGG-3' & 5'-ССТСТАAAAATAATAATAAATССТC-3' & 52 & Taql \\
\hline & $(p o l)$ & 2nd & 5'-GGGTTTTTTGATTTGTTTAGTTTG-3' & 5'-AAACTTACTAAAAAAATATCATCC-3' & 51 & \\
\hline & 4187 & Ist & 5'-GGGTGAAATTGTGTAGTTTTGTAGG-3' & 5'-ССТАTTTTCAAACGAATCTACСТCC-3' & 57 & Accll \\
\hline & $(p o l)$ & 2nd & 5'-GTGATTAGTAGGGTATTTGTGAGAG-3' & 5'-ATTATCACAAAAATCATTССССС-3' & 52 & \\
\hline & 5151 & Ist & 5'-GGTATTATTTTAAGTTTTTTGG-3' & 5'-CTCCAATTATAAAAATACAACAAC-3' & 46 & Taql \\
\hline & $(p o l)$ & 2nd & 5'-GTTAGTGGAAAGGATTATAGGAGG-3' & 5'-AACTTACCCATAATATTAAAAATC-3' & 51 & \\
\hline & 6113 & Ist & 5'-GGATTTATTGTTTTGATTTTTAG-3' & 5'-СТTТАСАТААТССТССТТАСТССС-3' & 51 & Taql \\
\hline & (env) & 2nd & 5'-GGATTTATTGTTTTGATTTTTAG-3' & 5'-CCCAAAACAAAAAATCAAAACC-3' & 53 & \\
\hline & 7258 & Ist & 5'-GAGGTGGYGTTTTTTTTTTTTGG-3' & 5'-ССТTAAAAATCTTAAAAATTCTC-3' & 47 & Taql \\
\hline & $(p X)$ & 2nd & 5'-AAGGATAGTAAATYGTTAAGTATAG-3' & 5'-CССAAATAATСТАATAСТСТАAAC-3' & 50 & \\
\hline & 8342 & Ist & 5'-YGATGGTAYGTTTATGATTTTYGGG-3' & 5'-АСССССТССТАAАСТАТСТСС-3' & 57 & Taql \\
\hline & (3'-LTR) & 2nd & 5'-YGATGGTAYGTTTATGATTTTYGGG-3' & 5'-AACTCCTACTAATTTATTAAACC-3' & 52 & \\
\hline & $5^{\prime}-L_{T R}^{b}$ & & 5'-GCTTTGCCTGACCCTGCTTGC-3' & 5'-AAGATTTGGCCCATTGCCTAGGG-3' & 63 & \\
\hline & env & & 5'-TGCCAGCCTCTCCACTTGGCACG-3' & 5'-ATGGAGCCGGTAATCCCGCCAGC-3' & 64 & \\
\hline & $\mathrm{pX}$ & & 5'-AAGGATAGCAAACCGTCAAGCACAG-3' & 5'-CCCAGGTGATCTGATGCTCTGGAC-3' & 63 & \\
\hline & 3'-LTR & & 5'-ССССТСАТTTСТАСТСТCACACGGC-3' & 5'-TGGGTGGTTCTTGGTGGCTTCCC-3' & 64 & \\
\hline
\end{tabular}

a Nucleotide position corresponding to that of ATK. This number means the cytidine of CpG sites analysed.

bFor ChIP assay, we used primers to amplify the indicated regions.

are shown in Table 1. The amplified PCR products were purified and subcloned into pGEM-T Easy vectors (Promega). For each region, at least 10 clones were sequenced using Big Dye Terminator v3.1 Cycle Sequencing Kit (Applied BioSystems, Foster City, CA) and ABI3100 autosequencer (Applied Biosystems).

\section{Combined bisulfite restriction analysis (COBRA)}

For COBRA, eight different regions of HTLV-I provirus were amplified with sodium bisulfite treated genomic DNAs using each primer sets as shown in Table 1. The nested PCR reactions were performed using FastStart Taq DNA Polymerase (Roche) with the following condition: 5 minutes at $95^{\circ} \mathrm{C}$ for denaturation, 40 cycles of $30 \mathrm{sec}$ at $95^{\circ} \mathrm{C}, 30 \mathrm{sec}$ at each annealing temperature (Table 1), 30 sec at $72^{\circ} \mathrm{C}$, and $2 \mathrm{~min}$ at $72^{\circ} \mathrm{C}$ for final extension. The PCR products were digested for at least $4 \mathrm{hrs}$ with an appropriate restriction enzyme (TaqI or AccII) that had a single recognition site within each product [38]. When CpG site within amplified region was methylated, it was resistant to sodium bisulfite treatment, resulting in digestion by these enzymes. On the other hand, since unmethylated CpG was converted to UG by sodium bisulfite treatment, these enzymes could not digest the amplified DNAs. The digested PCR products were separated in a 3\% Nusieve 3:1 agarose (BMA, Rockland, ME) gel. The intensity of each fragment was determined using ATTO Densitograph Ver. 4.0 (ATTO, Tokyo, Japan), and the extent of DNA methylation was calculated as follows: \% methylation $=100 \times($ digested PCR products/undigested + digested PCR products).

\section{Southern blot analyses}

To determine the number of integrated HTLV-I provirus, we performed Southern blot method using HTLV-I probe as described previously [10]. In brief, $5 \mu \mathrm{g}$ of DNA were digested with EcoRI, separated by electrophoresis in a $0.7 \%$ agarose gel, and transferred to nylon membrane (Hybond N+, Amersham Biosciences, Piscataway, NJ). The membrane was hybridized to the alkaline phospatase labeled pX probes. $0.9 \mathrm{~kb}$ PCR product of HTLV-I pX region derived from HTLV-I clone $\lambda 23-3$ was used as probe [39]. DNA probe was labeled, and hybridized to the membrane with Gene Images AlkPhos Direct Labelling and Detection system (Amersham Biosciences).

\section{Inverse-long PCR}

To check the HTLV-I integration in PBMCs of carriers, we analyzed the genomic DNAs from carriers by inverse-long PCR method as described previously [36]. In brief, genomic DNA was digested with EcoRI, and then ligated with T4 DNA ligase. Circularized DNA was digested with $\mathrm{MluI}$ that cut the provirus at $\mathrm{pX}$ region to prevent amplification of provirus itself. Then, treated genomic DNA was amplified with primers as follows: Long-IPCR-F: 5'TGCCTGACCCTGCTTGCTCAACTCTACGTCTTTG-3', Long-IPCR-R 5'-AGTCTGGGCCCTGACCTTTTCAGACTTCTGTTTC-3'. PCR condition was as follows: $2 \mathrm{~min}$ at $98^{\circ} \mathrm{C}$ for denaturation, 5 cycles $\left(30 \mathrm{sec}\right.$ at $98^{\circ} \mathrm{C}, 10 \mathrm{~min}$ at $64^{\circ} \mathrm{C}$ ), followed by $35 \mathrm{cycles}\left(30 \mathrm{sec}\right.$ at $94^{\circ} \mathrm{C}, 10 \mathrm{~min}$ at $64^{\circ} \mathrm{C}$ ) and $15 \mathrm{~min}$ at $72^{\circ} \mathrm{C}$ for final extension. The PCR products were subcloned into plasmid DNA and their sequences were determined. 
Table 2: Primer sets and annealing temperatures for genome specific PCR

\begin{tabular}{|c|c|c|c|c|c|c|}
\hline & Case & Locus & & Forward primer & Reverse primer & Anneal $\left({ }^{\circ} \mathrm{C}\right)$ \\
\hline \multirow[t]{12}{*}{ Primers for case } & Acute ATL I & $5 q 11.1$ & Ist & 5'-TTTGGAGAGGGAATTTTATATTG-3' & 5'-АСССССТССТАААСТАТСТСС-3' & 55 \\
\hline & & & 2nd & 5'-GGAGTGTAGAGATGTAGTTTTGG-3' & 5'-АСССССТССТАААСТАТСТСС-3' & 50 \\
\hline & Acute ATL 2 & $8 p 23.1$ & Ist & 5'-GAGAAATTTGTGTTGATTTTATTAG-3' & 5'-AСССССТССТАААСТАТСТСС-3' & 47 \\
\hline & & & 2nd & 5'-TTAGTGGTAGATTAAGTTAAAG-3' & 5'-АСССССТССТАААСТАТСТСС-3' & 45 \\
\hline & Acute ATL 3 & $\mid q 31.1$ & Ist & 5'-GGTAGAAATTATAGGTTTTTGTAGG-3' & 5'-АСССССТССТАААСТАТСТСС-3' & 51 \\
\hline & & & 2nd & 5'-GTTATTTGTGAAGTAAGATGTTTTG-3' & 5'-АСССССТССТАААСТАТСТСС-3' & 53 \\
\hline & Acute ATL 21 & $15 q 24.3$ & Ist & 5'-GAGGTGGATTTTTATTTTATTG-3' & 5'-АСССССТССТАААСТАТСТСС-3' & 52 \\
\hline & & & 2nd & 5'-GGTTTTTGATTATATTTGGGGGAG-3' & 5'-AСССССТССТАААСТАТСТСС-3' & 54 \\
\hline & Acute ATL 22 & $19 q 13.11$ & Ist & 5'-GTTAGTTGTTAGAGAGTTTTTTGG-3' & 5'-АСССССТССТАААСТАТСТСС-3' & 52 \\
\hline & & & 2nd & 5'-AAGATTATTTAGTTTTTTGGGG-3' & 5'-АСССССТССТАААСТАТСТСС-3' & 54 \\
\hline & Chronic ATL I & Ip22.1 & Ist & 5'-GGGTTTGAAGTTTTTTTTGTAGG-3' & 5'-АСССССТССТАААСТАТСТСС-3' & 53 \\
\hline & & & 2nd & 5'-AAGATTATTTAGTTTTTTGGGG-3' & 5'-ACССССТССТАAАСТАТСТCC-3' (5'-LTR U3) & 50 \\
\hline \multirow{12}{*}{$\begin{array}{l}\text { Primers for } \\
\text { human genome }\end{array}$} & & $5 q 11.1$ & Ist & 5'-TTTGGAGAGGGAATTTTATATTG-3' & 5'-CCCAAACTAATCTTCAACTCC-3' & 52 \\
\hline & & & 2nd & 5'-GGAGTGTAGAGATGTAGTTTTGG-3' & 5'-CСACCATAAAAAACССТССС-3' & 54 \\
\hline & & $8 p 23.1$ & Ist & 5'-GAGAAATTTGTGTTGATTTTATTAG-3' & 5'-AATATCACTATAACAATAACCAC-3' & 46 \\
\hline & & & 2nd & 5'-TTAGTGGTAGATTAAGTTAAAG-3' & 5'-СТСТСАACAAATTCCATCTTTCC-3' & 49 \\
\hline & & $|q 3| . \mid$ & Ist & 5'-GGTAGAAATTATAGGTTTTTTGTAGG-3' & 5'-CACCATTAAACAAACTAAATTCTC-3' & 51 \\
\hline & & & 2nd & 5'-GTTATTTGTGAAGTAAGATGTTTTG-3' & 5'-CACATAAAAAAACCCACACAATC-3' & 53 \\
\hline & & $15 q 24.3$ & Ist & 5'-GAGGTGGATTTTTATTTTATTG-3' & 5'-ATCTACCTAAAAAACCCACCC-3' & 52 \\
\hline & & & 2nd & 5'-GGTTTTTGATTATATTTGGGGAG-3' & 5'-AAAAACCCACCCAAACAAACC-3' & 57 \\
\hline & & $19 q 13.11$ & Ist & 5'-GTTAGTTGTTAGAGAGTTTTTTGG-3' & 5'-СААСТСССТАААСССТССТСС-3' & 52 \\
\hline & & & 2nd & 5'-GTTTTTTGGTTAAGGTTATGGG-3' & 5'-СТССТАCCACGAACCTACTCC-3' & 54 \\
\hline & & Ip22.1 & Ist & 5'-GGGTTTGAAGTTTTTTTTTGTAGG-3' & 5'-CAACAAAAACAATAAACAAAACC-3' & 54 \\
\hline & & & 2nd & 5'-AAGATTATTTAGTTTTTTGGGG-3' & 5'-СТTTACACCAATAAATTTAATACC-3' & 50 \\
\hline
\end{tabular}

\section{DNA methylation in neighboring regions of HTLV-I integration sites}

The integration sites of HTLV-I provirus has been determined by inverse long PCR, and DNA methylation of genomic DNAs neighboring integration sites was determined in both ATL cells and PBMCs. The nested PCR reactions were performed using FastStart Taq DNA Polymerase (Roche) with the following condition: $5 \mathrm{~min}$ utes at $95^{\circ} \mathrm{C}$ for denaturation, 40 cycles of $30 \mathrm{sec}$ at $95^{\circ} \mathrm{C}$, $30 \mathrm{sec}$ at each annealing temperature (Table 2), $30 \mathrm{sec}$ at $72^{\circ} \mathrm{C}$, and $2 \mathrm{~min}$ at $72^{\circ} \mathrm{C}$ for final extension.

\section{RT-PCR}

Total RNA was isolated from PBMCs or lymph node cells using TRIzol Reagent (Invitrogen, Carlsbad, CA) and RTPCR was performed using RNA LA PCR Kit (AMV) Ver. 1.1 (Takara Bio Inc., Otsu, Japan) according to the manufacturer's protocol. The tax and GAPDH gene transcripts were amplified using the following primers: RPX2 5'-CCGGCGCTGCTCTCATCCCGGT-3' and RPX5 5'-GGCCGAACATAGTCCCCCAGAG-3' (for tax), GAPDH1 5'ATGGGGAAGGTGAAGGTCGGAGTC-3' and GAPDH1a 5'-CCATGCCAGTGAGCTTCCCGTTC-3' (for GAPDH) under following conditions: 2 minutes at $95^{\circ} \mathrm{C}$ for denaturation, $35 \mathrm{cycles}$ of $30 \mathrm{sec}$ at $95^{\circ} \mathrm{C}, 30 \mathrm{sec}$ at $62^{\circ} \mathrm{C}, 30$ $\sec$ at $72^{\circ} \mathrm{C}$ (for tax), 25 cycles of $30 \mathrm{sec}$ at $95^{\circ} \mathrm{C}, 30 \mathrm{sec}$ at $55^{\circ} \mathrm{C}, 30 \mathrm{sec}$ at $72^{\circ} \mathrm{C}$ (for GAPDH) and $2 \mathrm{~min}$ at $72^{\circ} \mathrm{C}$ for final extension.

\section{Chromatin immunoprecipitation (ChIP) assay}

ChIP assays were performed as described previously [40]. Briefly, ATL cell lines and fresh ATL cells from ATL patients $\left(5 \times 10^{5}\right.$ cells/antibody) were fixed with formaldehyde and then sonicated to obtain soluble chromatin. The chromatin solutions were immunoprecipitated with antiacetyl-Histone $\mathrm{H} 3$ or anti-acetyl-Histone $\mathrm{H} 4$ (Upstate Biotechnology), or normal rabbit IgG, overnight at $4{ }^{\circ} \mathrm{C}$, and the immunoprecipitates were then collected with $50 \%$ protein A and G-Sepharose slurry preabsorbed with 0.1 $\mathrm{mg} / \mathrm{ml}$ sonicated salmon sperm DNA. The resulting purified DNAs were subjected to PCR reactions using primer sets specific for 5'-LTR, env, pX and 3'-LTR. The sequences of the primers are shown in Table 1 . To distinguish 5 ' and 3'-LTR, we used primers specific for gag and R region of LTR for amplification of 5'-LTR, and primers for $\mathrm{pX}$ region and U3 region were used for amplification of 3'-LTR. The PCR reactions were performed using FastStart Taq DNA Polymerase (Roche) with the following condition: $5 \mathrm{~min}$ utes at $95^{\circ} \mathrm{C}, 35$ or 37 cycles of $30 \mathrm{sec}$ at $95^{\circ} \mathrm{C}, 30 \mathrm{sec}$ at each annealing temperature (Table 1 ), 30 sec at $72^{\circ} \mathrm{C}$, and $2 \mathrm{~min}$ at $72^{\circ} \mathrm{C}$. The PCR products were electrophoresed in an agarose gel and the results were analyzed using ATTO Densitograph Ver. 4.0. Values were calculated as the signal intensity of each sample normalized by that of the whole cell extract.

\section{Statistical analyses}

Statistical analyses were performed using the Mann-Whitney's U-test and Student's t-test. 


\section{Competing interests}

The author(s) declare that they have no competing interests.

\section{Authors' contributions}

YT conceived this project and carriers out most of experiments in Figs. 1, 2, 3, 5 and 6. KN established COBRA assay and performed experiments in Figs. 1 and 2. JY performed experiments in Fig. 7. MM established most of HTLV-I transformed cell lines, and analyzed experiments in Fig. 4. AO and NM provided sequential DNA samples from seroconverters, and analyzed the data. M.Matsuoka directed and supervised the experiments and interpretations All authors read and approved the final manuscript.

\section{Acknowledgements}

We thank Shinjiro Hino for valuable suggestions.

\section{References}

I. Takatsuki K, Yamaguchi K, Matsuoka M: ATL and HTLV-I-related diseases. In Adult T-cell leukemia Edited by: Takatsuki K. New York: Oxford University Press; 1994: I-27.

2. Matsuoka M: Human T-cell leukemia virus type $I$ and adult Tcell leukemia. Oncogene 2003, 22(33):5I3I-5I40.

3. Yoshida M: Multiple viral strategies of HTLV-I for dysregulation of cell growth control. Annu Rev Immunol 200I, 19:475-496.

4. Franchini G, Fukumoto R, Fullen JR: T-cell control by human Tcell leukemia/lymphoma virus type I. Int J Hematol 2003, 78(4):280-296.

5. Jin DY, Spencer F, Jeang KT: Human T cell leukemia virus type I oncoprotein Tax targets the human mitotic checkpoint protein MADI. Cell 1998, 93(I):8I-91.

6. Jin DY, Giordano V, Kibler KV, Nakano H, Jeang KT: Role of adapter function in oncoprotein-mediated activation of NFkappaB. Human T-cell leukemia virus type I Tax interacts directly with IkappaB kinase gamma. J Biol Chem 1999, 274(25): I 7402- I7405.

7. Jacobson S, Shida H, McFarlin DE, Fauci AS, Koenig S: Circulating CD8+ cytotoxic T lymphocytes specific for HTLV-I pX in patients with HTLV-I associated neurological disease. Nature 1990, 348(6298):245-248.

8. Bangham CR: Human T-lymphotropic virus type I (HTLV-I): persistence and immune control. Int J Hematol 2003, 78(4):297-303.

9. Kannagi M, Ohashi T, Harashima N, Hanabuchi S, Hasegawa A: Immunological risks of adult $\mathrm{T}$-cell leukemia at primary HTLV-I infection. Trends Microbiol 2004, I 2(7):346-352.

10. Tamiya S, Matsuoka M, Etoh K, Watanabe T, Kamihira S, Yamaguchi K, Takatsuki K: Two types of defective human T-lymphotropic virus type I provirus in adult T-cell leukemia. Blood 1996, 88(8):3065-3073.

II. Furukawa Y, Kubota R, Tara M, Izumo S, Osame M: Existence of escape mutant in HTLV-I tax during the development of adult T-cell leukemia. Blood 200I, 97(4):987-993.

12. Koiwa T, Hamano-Usami A, Ishida T, Okayama A, Yamaguchi K, Kamihira S, Watanabe T: 5'-long terminal repeat-selective CpG methylation of latent human T-cell leukemia virus type I provirus in vitro and in vivo. J Virol 2002, 76(18):9389-9397.

13. Takeda S, Maeda M, Morikawa S, Taniguchi Y, Yasunaga J, Nosaka K, Tanaka Y, Matsuoka M: Genetic and epigenetic inactivation of tax gene in adult T-cell leukemia cells. Int J Cancer 2004, 109(4):559-567.

14. Verma M: Viral genes and methylation. Ann N Y Acad Sci 2003 , 983:170-180.

15. Han Y, Lassen K, Monie D, Sedaghat AR, Shimoji S, Liu X, Pierson TC, Margolick JB, Siliciano RF, Siliciano JD: Resting CD4+ T cells from human immunodeficiency virus type I (HIV-I)-infected individuals carry integrated HIV-I genomes within actively transcribed host genes. J Virol 2004, 78( I 2):6122-6133.
16. Doi K, Wu X, Taniguchi Y, Yasunaga Jl, Satou Y, Okayama A, Nosaka K, Matsuoka M: Preferential selection of human T-cell leukemia virus type I (HTLV-I) provirus integration sites in leukemic versus carrier states. Blood 2005.

17. Seiki M, Eddy R, Shows TB, Yoshida M: Nonspecific integration of the HTLV provirus genome into adult T-cell leukaemia cells. Nature 1984, 309(5969):640-642.

18. Jordan A, Bisgrove D, Verdin E: HIV reproducibly establishes a latent infection after acute infection of $T$ cells in vitro. Embo J 2003, 22(8): 1868-1877.

19. Seiki M, Inoue J, Hidaka M, Yoshida M: Two cis-acting elements responsible for posttranscriptional trans-regulation of gene expression of human T-cell leukemia virus type I. Proc Natl Acad Sci U S A 1 988, 85(19):7| 24-7| 28.

20. Zhang W, Nisbet JW, Albrecht B, Ding W, Kashanchi F, Bartoe JT, Lairmore MD: Human T-lymphotropic virus type I p30(II) regulates gene transcription by binding CREB binding protein/ p300. JVirol 200I, 75(20):9885-9895.

21. Nicot C, Dundr M, Johnson JM, Fullen JR, Alonzo N, Fukumoto R, Princler GL, Derse D, Misteli T, Franchini G: HTLV-I-encoded p30II is a post-transcriptional negative regulator of viral replication. Nat Med 2004, 10(2): 197-20I.

22. Gaudray G, Gachon F, Basbous J, Biard-Piechaczyk M, Devaux C, Mesnard JM: The complementary strand of the human T-cell leukemia virus type I RNA genome encodes a bZIP transcription factor that down-regulates viral transcription. J Virol 2002, 76(24): I28I3-I2822.

23. Miyoshi H, Smith KA, Mosier DE, Verma IM, Torbett BE: Transduction of human CD34+ cells that mediate long-term engraftment of NOD/SCID mice by HIV vectors. Science 1999, 283(5402):682-686.

24. Gatlin J, Padgett A, Melkus MW, Kelly PF, Garcia JV: Long-term engraftment of nonobese diabetic/severe combined immunodeficient mice with human CD34+ cells transduced by a self-inactivating human immunodeficiency virus type I vector. Hum Gene Ther 200I, I 2(9): 1079-I089.

25. Pion M, Jordan A, Biancotto A, Dequiedt F, Gondois-Rey F, Rondeau S, Vigne R, Hejnar J, Verdin E, Hirsch I: Transcriptional suppression of in vitro-integrated human immunodeficiency virus type I does not correlate with proviral DNA methylation. J Virol 2003, 77(7):4025-4032.

26. Schroder AR, Shinn P, Chen H, Berry C, Ecker JR, Bushman F: HIV$I$ integration in the human genome favors active genes and local hotspots. Cell 2002, I I0(4):52I-529.

27. Larocca D, Chao LA, Seto MH, Brunck TK: Human T-cell leukemia virus minus strand transcription in infected T-cells. Biochem Biophys Res Commun 1989, 163(2): 1006-1013.

28. Takai $D$, Jones PA: Comprehensive analysis of $\mathbf{C p G}$ islands in human chromosomes 21 and 22. Proc Natl Acad Sci U S A 2002, 99(6):3740-3745.

29. Nosaka K, Maeda M, Tamiya S, Sakai T, Mitsuya H, Matsuoka M: Increasing methylation of the CDKN2A gene is associated with the progression of adult T-cell leukemia. Cancer Res 2000, 60(4): $1043-1048$.

30. Furuta RA, Sugiura K, Kawakita S, Inada T, Ikehara S, Matsuda T, Fujisawa J: Mouse model for the equilibration interaction between the host immune system and human T-cell leukemia virus type I gene expression. J Virol 2002, 76(6):2703-27I3.

3I. Hanabuchi S, Ohashi T, Koya Y, Kato H, Hasegawa A, Takemura F, Masuda T, Kannagi M: Regression of human T-cell leukemia virus type I (HTLV-I)-associated lymphomas in a rat model: peptide-induced T-cell immunity. I Natl Cancer Inst 200I, 93(23): $1775-1783$.

32. Soengas MS, Capodieci P, Polsky D, Mora J, Esteller M, Opitz-Araya X, McCombie R, Herman JG, Gerald WL, Lazebnik YA, et al.: Inactivation of the apoptosis effector Apaf-I in malignant melanoma. Nature 200I, 409(68I7):207-2।I.

33. Yasunaga J, Taniguchi Y, Nosaka K, Yoshida M, Satou Y, Sakai T, Mitsuya $H$, Matsuoka M: Identification of aberrantly methylated genes in association with adult T-cell leukemia. Cancer Res 2004, 64(I 7):6002-6009.

34. Bachman KE, Park BH, Rhee I, Rajagopalan H, Herman JG, Baylin SB, Kinzler KW, Vogelstein B: Histone modifications and silencing prior to DNA methylation of a tumor suppressor gene. Cancer Cell 2003, 3(I):89-95. 
35. Lemasson I, Polakowski NJ, Laybourn PJ, Nyborg JK: Transcription regulatory complexes bind the human T-cell leukemia virus ${ }^{\prime}$ ' and $3^{\prime}$ long terminal repeats to control gene expression. Mol Cell Biol 2004, 24(14):6 I 17-6I26.

36. Etoh K, Tamiya S, Yamaguchi K, Okayama A, Tsubouchi H, Ideta T, Mueller N, Takatsuki K, Matsuoka M: Persistent clonal proliferation of human T-lymphotropic virus type I-infected cells in vivo. Cancer Res 1997, 57(21):4862-4867.

37. Yasunaga J, Sakai T, Nosaka K, Etoh K, Tamiya S, Koga S, Mita S, Uchino M, Mitsuya $\mathrm{H}$, Matsuoka M: Impaired production of naive $\mathbf{T}$ lymphocytes in human T-cell leukemia virus type l-infected individuals: its implications in the immunodeficient state. Blood 200I, 97(10):3177-3183.

38. Xiong Z, Laird PW: COBRA: a sensitive and quantitative DNA methylation assay. Nucleic Acids Res 1997, 25( I 2):2532-2534.

39. Clarke MF, Gelmann EP, Reitz MS Jr: Homology of human T-cell leukaemia virus envelope gene with class I HLA gene. Nature 1983, 305(5929):60-62.

40. Hino S, Fan J, Taguwa S, Akasaka K, Matsuoka M: Sea urchin insulator protects lentiviral vector from silencing by maintaining active chromatin structure. Gene Ther 2004, II(I0):819-828.

41. Seiki M, Hattori S, Hirayama Y, Yoshida M: Human adult T-cell leukemia virus: complete nucleotide sequence of the provirus genome integrated in leukemia cell DNA. Proc Natl Acad Sci U S A 1983, 80(12):3618-3622. 